\title{
Saints on Stage: An Analytical Survey of Dramatic Records in the West of England
}

In the past couple of decades there has been some fresh attention given to study of the saint play, a hitherto neglected genre of English medieval drama. ${ }^{1}$ Although there continues to be a dearth of known surviving texts, rediscovery and re-editing of historical records of the period have inspired essays by Lawrence Clopper, Clifford Davidson, and John Wasson, among others. ${ }^{2}$ There is no easy agreement in their reassessments of the evidence, however. Wasson and Davidson are in harmony, suggesting that '[d]ramatic records from English sources which have survived do indeed indicate that the miracle or saint play may even have been the most important genre in the repertoire of the English medieval stage ... there was a great flourishing of this genre up to the time of the Reformation' and 'that of the early religious drama far more were saint plays than were Corpus Christi, morality, Christmas, Easter, or other mystery plays'. ${ }^{3}$ Clopper takes the opposite viewpoint, challenging almost all of the records previously interpreted as evidence for saint plays, 'sceptical there were ever many saint plays in England in the later medieval period up through the Reformation or during the reign of Mary ... we have lumped together a variety of lay and clerical activities held on saints' feastdays as saint plays when the records cannot support the contention that they are enactments of the vita of a saint'.

My purpose in this essay is to focus on the accumulation of dramatic records for a broad region in the west of England where REED's research is complete apart from the county of Cheshire in the northwest. I will therefore be excluding in my discussion many of the references so helpfully listed in Clifford Davidson's website, 'Saint Plays and Pageants of Medieval Britain', <http://www.wmich.edu/medieval/research/edam/index.html>. Of more than 100 possible records of saint plays and pageants itemized by Davidson, I am dealing here with approximately 20 per cent, so my conclusions are regional and not intended to join in the larger debate about saint plays elsewhere in the British Isles. This essay is the first stage of my study of parish festive 
traditions in the west of England for a proposed history of regional entertainment in England before 1642.

Taking up this study in 1998, I have the advantage of ready access to more than was available to Clopper, Davidson, and Wasson, though I will be referring to many of the same records. The map ( $p$ 54) illustrates the western counties from north to south - Cumberland, Westmorland, Lancashire, Cheshire, Shropshire, Worcestershire, Herefordshire, Gloucestershire, Bristol, Somerset, Dorset, Devon, Dorset, and Cornwall - and locates the places where saint plays or related customs have been found. Like Clopper, I interpret the term 'saint play' as the dramatic enactment of a saint's life or of a momentous event or 'miracle' forming part of a saint's biography. Not included are plays typically associated with the biblical cycle productions such as the Assumption of the Virgin at Chester.

A first response to the results of a survey of thirteen REED collections from the west is, to paraphrase Harold C. Gardiner, that it remains a 'puzzle why there are so few records of the existence of miracle plays, as distinct from the mysteries.' ${ }^{\prime}$ Not only were there numerous village parish and civic craft guilds dedicated to saints in the late medieval period, but it is also vividly apparent from surviving iconography and will bequests that popular devotion to the saints remained widely prevalent in the west up to the Reformation. ${ }^{7}$ Was the veneration of saints otherwise expressed? Were the dramatic efforts of local church and civic leaders devoted to instructing the laity in the biblical essentials of the faith rather than through the non-biblical miracles and martyrdom of the saints?

We might hope to find evidence for medieval saint plays in the accounts of a variety of possible producers - monasteries, cathedrals, religious and craft guilds, larger towns, or parish churches. The records of the English west cover all these categories, although for obvious reasons there is less to be found from the once great monastic collections and the numerous religious guilds. ${ }^{8}$ Some counties, like Gloucestershire, Lancashire, and Westmorland, have few relevant documents of any kind surviving from the late medieval period, but others, like Devon and Somerset, are rich in cathedral, civic, and parish (including religious guild) records. Yet these representative collections from well populated and prosperous counties with well endowed parish churches have not yielded many saint plays. In fact, the only play on record which may have featured a saint in either county is a rather shadowy one at the stannary town of Ashburton in southwestern Devon.

St Andrew's Church, Ashburton, had mounted plays at Christmas or Corpus Christi tide for a number of years in the early sixteenth century. Some- 
times the costumes mentioned are for Robin Hood and his cohorts, other items suggest a biblical subject. Only during the Marian revival, in 1555, does a Corpus Christi payment occur for two characters, God and St 'Rosmont' or 'Rosmonus'. ' There is no obvious candidate for the latter part. After much searching, only one possibility, and that a tenuous one, has occurred to me: 'Rosmont' may be a corrupted spelling of Rumon, reputed to have Christianized Devon and Cornwall from Glastonbury in the sixth century. Tavistock Abbey (not far from Ashburton), the church of Romansleigh in north Devon, and three Cornish parishes were dedicated to St Rumon whose vita had been resourcefully embellished by his biographer with incidents from the tenth-century life of the Breton St Ronan. ${ }^{10}$ But there is no evidence for a local cult of St Rumon at Ashburton, so it seems unlikely that the parish would have mounted a unique saint play dedicated to his life at Corpus Christi tide. This reference may have to remain an enigma.

Far more typical of Devon and Somerset were the parish-mounted Robin Hood plays or the civic-sponsored performances by the many companies of entertainers from elsewhere that toured the southwest, encouraged, one assumes, by appreciative audiences. This is not to say that there were no other activities linked with saints' days. The most widespread custom was commonly associated with the feast of St Nicholas, one of the most popular saints in Europe. This was the boy bishop ceremony, observed at the cathedrals of Wells and Exeter during the month of December from the early fourteenth century at least, as well as at the collegiate church of Ottery St Mary and at Cowick Priory, a dependent cell of Tavistock Abbey. ${ }^{1 ~}$ Similarly, a payment to the 'Clericis sancti Nicholai' in the 1538-9 Glastonbury Abbey Obedientiaries' Accounts is probably related to a resident boy bishop ceremony at Glastonbury, where there was both an almonry and a choir school. ${ }^{12}$ It seems likely, however, that the Cowick Priory payment, listed under external expenses, was for a visiting boy bishop, from neighbouring Exeter Cathedral or from the mother house at Tavistock where there was a school. ${ }^{13}$ An even more opaque entry, in the $1405 / 6$ Luttrell household accounts, notes a Christmastide payment to 'Clericis sancti Nicholai', not at home in Dunster Castle but at Bridgwater. ${ }^{14}$ There was no obvious base for the custom in this Somerset market town, so we can only speculate that the 'clerici' may have been a boy bishop's retinue touring from the nearby cathedral of Wells.

Hereford Cathedral, in the West Midlands, also maintained the boy bishop custom until the Reformation, and it is possible that a stray reference to a boy bishop payment in Gloucester by the king in 1283 might have been further embellished by monastic accounts had they survived. The likeliest home for 
the boy bishop ceremony in the thirteenth century would not have been St Peter's Abbey (later to become the Cathedral), but rather nearby Llanthony Priory, which ran the only school in the period in Gloucester. Although the record's use of the term 'miracula' might seem to imply more than the usual boy bishop custom, I agree with Clopper's assessment that the alms paid by the king on or near St Nicholas' Day were no more than a customary payment to choirboys and their mock bishop, rather than payment for a saint play. ${ }^{15}$ More than a century later, Llanthony Priory and St Oswald's, the other house of Augustinian canons in Gloucester, recorded, among other matters, their agreement to choose a boy bishop for the ceremonies of St Nicholas Day, and to divide the offerings collected in school for the bishop'. ${ }^{16}$ There is further corroboration of local St Nicholas customs in a mock sermon which survives from the period of Marian revival, but this boy bishop was chosen from the ranks at the new Gloucester Cathedral choir school to preach on 28 December $1558 .{ }^{17}$

The only other boy bishop custom known on record in the west is an interesting example from the parish church of St Nicholas in Bristol described in detail by Ricart, an early civic chronicler writing in the late fifteenth century. ${ }^{18}$ Like the other religious institutions named above, St Nicholas is known to have had a choir school by the second half of the fifteenth century. ${ }^{19}$

But a boy bishop custom, however mimetic, is not a saint play, nor is a church ale. Among the most confusing parish records to interpret are those concerning St George, whose feast on 23 April was a popular springtime event across the country, especially after Archbishop Chichele decreed that it be observed as a 'greater double' (major) festival in $1415 / 16 .^{20}$ There were numerous churches and religious guilds dedicated to the warrior saint, whose armoured image with the dragon featured in countless chapels. ${ }^{21}$ In the medieval period, festive liturgies, guild ridings, and parish ales occurred on the sain's day and even after the Reformation, the date continued to be marked on the civic calendars of some locations such as Chester where an annual St George's Day race was established in $1610 .^{22}$

Where late medieval parish guild accounts do survive, typically embedded in records classified as churchwardens' accounts, we have the opportunity to test a common assumption that St George plays were among the most popular in the period..$^{23}$ In Devon, for example, John Wasson located representative records of St George's parish guilds from St Brannock's, Braunton; St Michael's, Chagford; Holy Trinity, Exeter; St George's, Morebath; St Andrew's, South Tawton; and All Saints, Winkleigh. However, these records have produced very slim pickings. The parishes were more likely to hold ales than mount saint 
plays as part of their annual festivities and only Morebath has been put forward as a producer of a St George play. ${ }^{24}$ But despite suggestions that the parish guild of St George, Morebath, mounted a play in honour of its patron saint, the records evidence is unconvincing. In their fuller context, the detailed payments for making a new George and horse and for 'owr dragon' in 1531 seem clearly to relate to the renewal of the church's image of St George. ${ }^{25}$ The streamer purchased for St George's Day in 1541 and listed in the 1548 inventory with a banner depicting St George on one side and St Sidwell on the other were, as Wasson suggests, undoubtedly for processions. ${ }^{26}$ These are typical items to be expected in the accounts of religious guilds responsible for maintaining the chapel of their patron saint in the local parish church. ${ }^{27}$ Other predictable routine payments are linked with the annual communal feast. At Morebath, those for cleaning the churchyard at St George's tide $(1538,1540,1541,1544,1545,1546$, and 1547) are most likely for the annual ale held on the Sunday nearest St George's Day. A 1540 entry, not clearly linked with any specific event during the year, lists costs for items such as boards and trestles which could be for the ale, although the reference to 'pe cete in the churche yerde' has been interpreted as the set for a 'city' rather than what could simply be 'seats' or 'benches'. ${ }^{28}$ However, in no account, including this one, is direct reference made to a St George's play, in the form of receipts or costs for costumes, props, or actors as one would expect nor do costumes appear in the 1548 inventory. ${ }^{29}$

Given the dearth of evidence generally, I think we should question whether a relatively small parish such as Morebath would be either capable of or inclined to mount anything as ambitious as a saint play. Duffy, who has recently studied the Morebath records in detail, describes the parish as 'a tiny community', 'close-knit and largely self-contained', principally concerned in this transitional era with maintaining its church fabric and vestments. ${ }^{30} \mathrm{Far}$ more likely for such rural parishes would have been the less demanding, always entertaining Robin Hood plays which Wasson and others have found clear evidence for in the accounts of late medieval and sixteenth-century parish summer revels across the southwest.

More mimetic activities featuring St George do occur in the west, although the only actual play on record may be questioned. It appears in a seventeenth-century antiquarian mayor's list or chronicle as an isolated occurrence in the city of Chester some three centuries earlier. ${ }^{31}$ Without more contemporary witnesses, we may wonder whether the desire for a long-standing civic tradition focusing on St George might not have influenced an antiquarian with local pride writing in the period of the St George's Day race. 
What is more certain is that St George appeared most frequently as a character in elaborate civic pageants, usually in honour of visiting royalty. At Bristol in 1461, a pageant depicted St George fighting the dragon to the accompaniment of heavenly music as part of a series of visual spectacles to welcome Edward Iv. ${ }^{32}$ When Henry vil came to Hereford in 1486 , he was greeted first by St George, the focal point of a pageant set up by the city gate, to be followed by the martyr king, Ethelbert, at the second station and the Virgin Mary at the third..$^{33}$ And long after the Reformation had largely repressed the cult of the saints, St George would feature in Chester's processional triumph in honour of Prince Henry in 1610 and in Wells' welcome to Queen Anne in $1613 .{ }^{34}$ At Wells, St George seems also to have been the patron saint of the Mercers' guild, which produced the pageant in 1613, as well as a similar one in mid-June 1607 , as a segment in an extraordinary and controversial series of festive events over a two-month period. Because St George had been generally accepted as patron saint of England from the time of Edward III, these continuing appearances before royalty are not so remarkable. More surprisingly at Wells in 1613, in what may have been a defiantly conservative display for a sympathetic queen, other guild saints rode in pageants, such as the Tanners', Chandlers', and Butchers' St Clement and the Cordwainers' St Crispin and St Crispinian. ${ }^{35}$

The only other mimetic activity featuring St George in the west occurs in the accounts of Lostwithiel, administrative centre of the duchy of Cornwall. Like some of the Devon locations, Lostwithiel has surviving pre-Reformation accounts of its St George's guild, for the year $1536-7 .{ }^{36}$ Alongside routine payments for maintenance of the saint's shrine and masses are expenses for the guild's annual riding. It is apparent that guild members were accompanied by a costumed St George as they paraded through the town, although there is no sign of the dragon which featured in similar festive ridings in other parts of the kingdom, such as Norwich. ${ }^{37}$

If customs relaring to the ever-popular St George and St Nicholas are the most numerous in western England, in the final analysis there is no certain contemporary evidence for corresponding saint plays. In fact, the only saint play text surviving from the region is devoted to Meriasek, primarily a Breton saint who had one church dedicated to him in Cornwall at Camborne, where the play manuscript originated. Although we know that the play is indeed a saint's life, probably written around 1500 for performance in the round over two days, we have no records of its production or sponsorship. ${ }^{38}$ This saint play, the dramatic expression of a Celtic cult in the extreme southwest of England, is scarcely typical of other locations in the English west and 
was certainly more subject to influences from continental Brittany than the other areas under consideration.

Duffy has reflected at some length about the growth of devotion to the female martyr saints in the later Middle Ages. The virgin martyrs had developed a special appeal as sympathetic intercessors, especially for women, an appeal confirmed by their frequent appearance in church iconography and by their popularity in widely circulated lives of the saints such as the Legenda Aurea. ${ }^{39}$ One of the most popular was St Katherine of Alexandria, whose legend was one of the more frequently represented subjects in late medieval English churches. ${ }^{40}$ Although Clopper discounts the play attributed to her in the west, by analogy with the early twelfth-century 'miraculum' at Dunstable, his argument is not entirely persuasive in this instance. ${ }^{41}$ The St Katherine's 'play', as described in more than one Shrewsbury document for 1526, is not the mimetic gathering custom associated with the saint's festival in late November, but rather a special civic event produced at Whitsuntide with the help of contributions from aldermen, the common council, and guildsmen. ${ }^{42}$ Some of the detailed payments survive in the civic accounts, indicating a level of expense consistent with an ambitious production rather than a mere folk play or game. ${ }^{43}$ Shrewsbury was the most important borough in its county, with several churches, three friaries, thirteen craft guilds, and several religious guilds, including the elite guild dedicated to $S t$ Winifred, a Welsh virgin martyr whose relics were held by St Peter's Abbey. There was a chapel dedicated to St Katherine in the abbey church too, as well as three religious guilds dedicated to her in the town, including one at the church of St Julian (yet another virgin martyr). ${ }^{44}$ It would seem that Shrewsbury had not only the civic resources but also the local devotional cults that might have inspired the production of female saint plays.

Alan Somerset has identified what he calls a thriving tradition of civic religious drama' at Whitsuntide in the Shrewsbury records, although we cannot always determine the subjects of the plays. Aside from the $1526 \mathrm{St}$ Katherine play, one other of the three titled plays before the Reformation is known to have focused on two female saints. At Whitsuntide 1516, the abbot of St Peter's and his monks were entertained by the town at 'ludum et demonstracionem Martiriorum' of Saints Feliciana and Sabina in the large semi-circular quarry which had been used as an outdoor theatre space from the mid-fifteenth century (in this case we know more about the audience and the performance space than we do about the production costs). ${ }^{45}$

Shrewsbury, home of an important shrine to a female virgin saint, is a likely urban centre for production of saint plays such as the two on record. Two 
other cities in the west also have mimetic records featuring St Katherine, but neither instance falls into the same category as Shrewsbury. At Hereford the Journeymen Cappers presented a pageant of St Katherine as their contribution to an otherwise conventional series of twenty-seven guild-produced, biblical tableaux vivants for the Corpus Christi procession which is spottily recorded between 1503 and $1548 .{ }^{46}$ There is no evidence here of a scripted play.

A more familiar custom associated with the eve of St Katherine's feast is infrequently recorded in England although Ricart chronicled the activity in late fifteenth-century Bristol. This was a processional gathering, usually featuring women or children with a representative of the saint in their midst, collecting tribute at the doors of prominent citizens as they went. In Bristol, after evensong at the Weavers' chapel of St Katherine in Temple Church and hospitality at the guild's hall, the city dignitaries dispersed to their homes to receive the St Katherine 'players' for drinks and rewards at their doors. From Ricart's description it is clear that these St Katherine Eve 'playes' were the traditional door to door gathering custom rather than what we would interpret as a saint play to set alongside the staged production in Shrewsbury. ${ }^{47}$

In the final analysis there is very little evidence from these western counties to support the contention that saint plays were the most important dramatic genre before the Reformation. But perhaps we should distinguish a regional difference in this case? Catherine Dunn, another modern scholar who has puzzled over the scarcity of surviving English miracle plays, has pointed out that 'the records of lost dramas once performed in Britain are quite abundant, especially for the eastern and southern sections of England'. ${ }^{8}$ East Anglia and the southeast may indeed prove to be the principal areas for the production of saint plays, but if so, our re-examination suggests that this could be a regional phenomenon, perhaps partly because the east coast was more subject to direct influence from France and the Low Countries than the counties of the west. ${ }^{49}$ Certainly the tally of likely saint plays in the west argues against the genre being widespread there, even if we allow for the loss of records after the Dissolution of monasteries and religious guilds in the $1540 \mathrm{~s}$. We still have access to an interesting, if incomplete, range of records - medieval civic documents from Exeter, Barnstaple, Bridgwater, Bodmin, Launceston, and Shrewsbury, as well as early Tudor accounts from Bristol, Plymouth, Poole, Hereford, and Chester; a variety of late medieval parish guild and churchwardens' accounts from several counties; and extensive runs of cathedral accounts from Exeter, Hereford, Worcester (monastic), and Wells. Any of these sources might have furnished us with the production 
records of saint plays, but only the early sixteenth-century urban centre of Shrewsbury has yielded some persuasive, if spare evidence of two virgin martyr plays. The exceptional Cornish play text of St Meriasek has stronger links with continental Brittany than with English tradition and it is notable that there are no local production records of it or any other saint play in Cornwall, despite the county's remarkable number of Celtic cults.

It seems that the parishes in the west had other activities to sponsor. There is ample evidence in the west of the shrines, relics, chantries, and pilgrimage centres that were characteristic of late medieval European piety but the festive liturgical observances on saint days were probably the usual means of commemorating their holy lives and martyrdoms. The visual expression of popular devotion to the saints did occur in western parishes, but it appears to have taken principal form in the imagery, painted glass, rood screens, and liturgical vestments for local churches which continued to be endowed by both men and women up to the Reformation. In such iconography the lives of the saints could be vividly illustrated and their presence evoked in the daily lives of the faithful. As far as we can tell, the local dramatic impulse was not as ambitiously inclined as East Anglia's, for example, but more typically directed towards modest folk plays such as Robin Hood, featured at annual church ales and summer games from Cornwall to Shropshire. 
54 SALLY-BETH MACLEAN

\section{Appendix 1}

\section{Locations for Dramatic Records of Saints in the West of England}

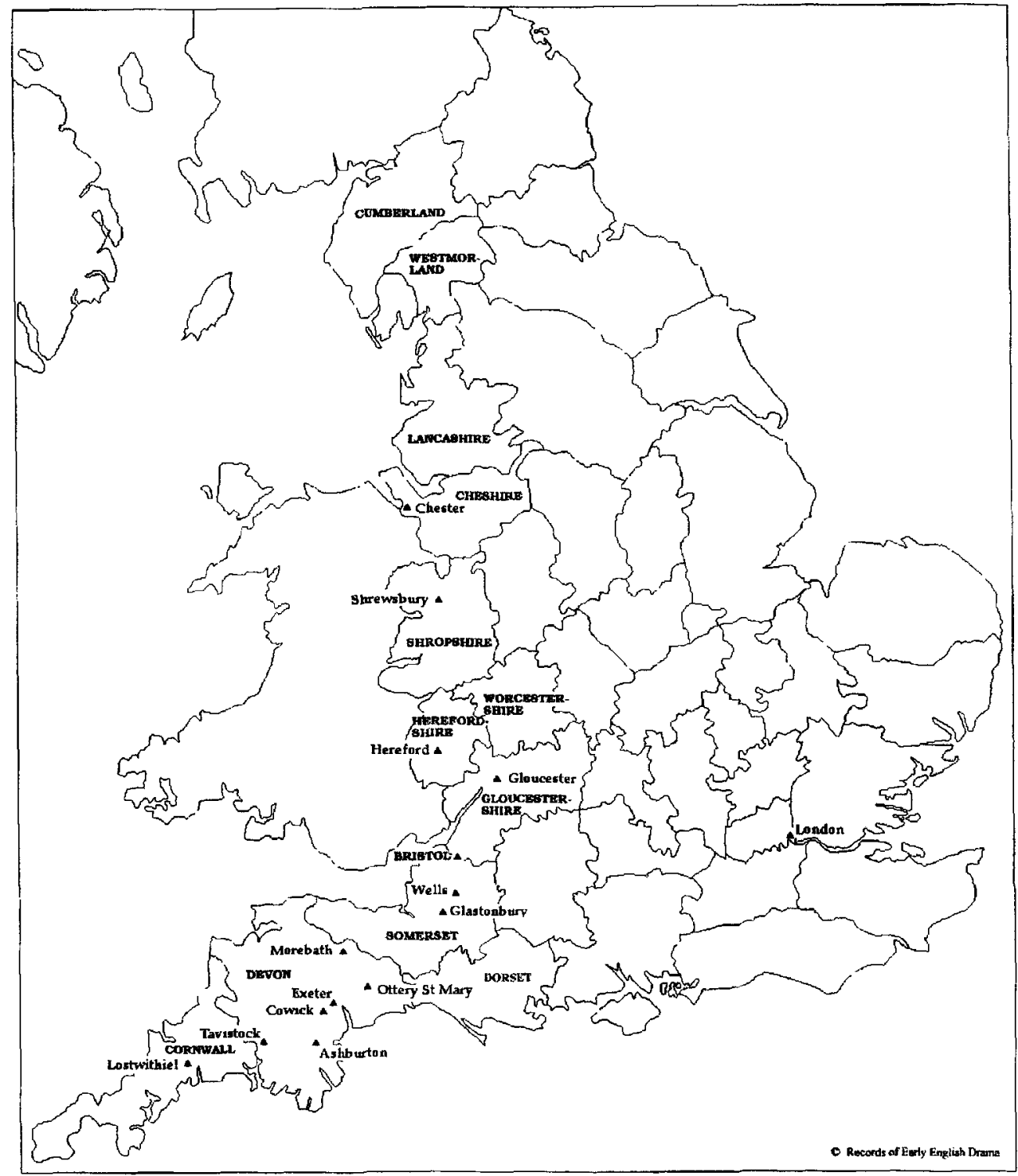




\section{Appendix 2}

Dramatic Records of Saints Located in the West of England

This summary chart is an attempt to differentiate likely saint plays from other forms of entertainment or ritual activity relating to non-biblical saints found in the west of England where REED research has been completed (with the exception of the county of Cheshire). REED collections for Cumberland, Westmorland, Lancashire, Chester, Shropshire, Worcestershire, Herefordshire, Gloucestershire, Bristol, Somerset, Dorset, Devon, and Cornwall have been surveyed, as well as the website list, 'Saint Plays and Pageants of Medieval Britain', prepared by Clifford Davidson..$^{\text {sn }}$

Saint Plays $(3+1$ uncertain $)$

Sts Feliciana and Sabina

Shrewsbury Whitsun week 1516 auspices unknown

St George?

Chester

23 April 1431

auspices unknown

(17th c. antiquarian notice)

St Katherine of Alexandria

Shrewsbury c. Corpus Christi 1526 civic auspices

St Meriasek

Camborne? c. 1500 auspices unknown

Pageants (with speeches $\& /$ or music) (3 royal entries)

St Ethelbert

Hereford 15 May 1486 civic auspices

St George

Bristol 9 September $1461 \quad$ civic auspices 
56 SALLY-BETH MACLEAN

St George (cont)

Hereford 15 May 1486

Chester

23 April 1610

Pageants (dumb shows?) (2 locations)

St Clement

Wells

20 August 1613

St Crispin and Crispinian

Wells

20 August 1613

St George

Wells

17 June 1607

Wells

20 August 1613

St Katherine of Alexandria

Hereford

Corpus Christi 1503

$-c .1548$

Guild Ridings (1 location)

St George

Lostwithiel 23 April 1537

Festive Customs (9 locations)

St George's Ale

Morebath 23 April 1538+ civic auspices

civic auspices

Tanners, Chandlers, and

Butchers' guilds

Cordwainers' guild

Mercers' guild?

Mercers' guild

Journeymen Cappers'

pageant

St George's guild

(parish)

St George's guild

(parish) 


\section{St Katherine of Alexandria Gathering}

Bristol 24 November eve, 15th c. Weavers' guild

St Nicholas Boy Bishop Ceremonies

$\begin{array}{lll}\text { Hereford } & 28 \text { December } c 1265-c .1544 & \text { secular cathedral } \\ \text { Gloucester } & 6 \text { December } 1283-16 \text { th c.? } & \begin{array}{l}\text { Augustinian priory } \\ \text { secular cathedral }\end{array} \\ & 28 \text { December } 1558 & \text { secular cathedral } \\ \text { Exeter } & 28 \text { December } 1326-c .1527 & \text { secular cathedral } \\ \text { Wells } & 28 \text { December } 1327-c .1537 & \text { collegiate church } \\ \text { Ottery St Mary } & \text { 14th c. } & \text { auspices unknown } \\ \text { Bridgwater } & 5 \text { January } 1405 / 6 & \text { Benedictine priory } \\ \text { Cowick Priory } & \text { c. } 1475 & \text { St Nicholas parish } \\ \text { Bristol } & \text { 6 December, 15th c.-early } & \\ & \text { 16th c. }\end{array}$


Notes

1 My survey of published work in the field supports Glynne Wickham's observation in 1969 that 'none of the several types of drama popular in the Middle Ages has attracted less attention from theatre historians and critics of literature'. See Glynne Wickham, 'The Staging of Saint Plays in England', The Medieval Drama, Sandro Sticca (ed) (Albany, NY, 1972), 100.

2 John Wasson has written several articles which draw upon his records research for the REED volume on Devon (Toronto, 1986) and the Norfolk/ Suffolk Malone Society Collections 11 (Oxford, 1980/1), notably 'The St. George and Robin Hood Plays in Devon', Medieval English Theatre 2 (1980), 66-9, and 'The Secular Saint Plays of the Elizabethan Era', in The Saint Play in Medieval Europe, Clifford Davidson (ed), Early Drama, Art, and Music Series 8 (Kalamazoo, MI, 1986), 241-60. Clifford Davidson's article, 'The Middle English Saint Play and Its Iconography', also appeared in the latter volume, 31-122 and, more recently, 'Saints in Play: English Theatre and Saints' Lives', in Saints: Studies in Medieval Hagiography, Sandro Sticca (ed), Medieval and Renaissance Texts and Studies 141 (Binghamton, NY, 1996), 145-60. Lawrence Clopper has published two challenging articles on the subject, 'Miracula and The Tretise of Miraclis Pleyinge', Speculum 65 (1990), 878-905, and 'Communitas: The Play of Saints in Late Medieval and Tudor England', in Mediaevalia 18 (1995), 81-109.

3 Davidson, 'The Middle English Saint Play', 31, and Wasson, 'Secular Saint Plays of the Elizabethan Era', 241.

4 Clopper, 'Communitas,' 81. See also Clopper's arricle, 'Miracula and The Tretise of Miraclis Pleyinge', on English medieval uses of the terms 'miracula' and 'spectacula.'

5 Alexandra F. Johnston and I are collaborating on this history of regional theatre (excluding London and the universities), starting with a volume on the western region. I am grateful to the Social Sciences and Humanities Research Council of Canada for their funding support of this project.

6 Harold C. Gardiner, Mysteries End: An Investigation of the Last Days of the Medieval Religious Stage (New Haven, CT, 1946), 54.

7 See, for example, Eamon Duffy's wide-ranging evidence for flourishing saints' cults in England, The Stripping of the Altars: Traditional Religion in England c. 1400-c. 1580 (New Haven and London, 1992), 155-205.

8 For the impact of the Reformation on parish guilds see H.F. Westlake, The Parish Gilds of Mediaeval England (London, 1919), 132-6.

9 See Wasson, Devon, 28. Alison Hanham, editor of Churchwardens' Accounts of 
Ashburton, 1479-1580, Devon and Cornwall Record Society, ns, vol 15 (Torquay, 1970), 133, transcribes the name as 'Rosmonus' with the accompanying note: 'The ending of this name is unclear. The last character resembles a badly-written $t$ or $g$, but I take it to be the abbreviation sign for $u$, which looks like g.'

10 For further details see Gilbert H. Doble, The Saints of Cornwall, Part Two: Saints of the Lizard District (Oxford, 1962), 120-34. The principal feast of St Rumon was 30 August; his translation was 5 January. The chief guild in Ashburton was dedicated not to St Rumon but to St Laurence which had its own chapel. Little is known about the parish guilds at Ashburton although there were side altars in the parish church for St John, St Thomas of Canterbury, St Katherine, St Margaret, and the Blessed Virgin Mary (see H.J. Hanham, 'The Suppression of the Chantries in Ashburton', Report and Transactions of the Devonshire Association 99 (1967), 112, 115-16).

I am grateful for the thoughtful suggestions made by Dr Oliver Padel, whose knowledge of Celtic saints and philology has modified my interpretation of this baffling record.

11 See Nicholas Orme, Education in the West of England 1066-1548 (Exeter, 1976), 206, and James Stokes with Robert J. Alexander (eds), Somerset including Bath, REED, vol 1 (Toronto, 1996), 128. The election of the boy bishop typically occurred on or near 6 December, although the culmination of the ritual was on the feast of the Holy Innocents ( 28 December) when he presided at mass and preached a sermon. See further Warren W. Wooden, 'Childermass Ceremonies in Late Medieval England: The Literary Legacy', FifteenthCentury Studies 4 (1981), 195-205. Wooden's generalization (196) that 'by the late 15th century most English parish churches had their own Boy Bishop' has not been verified by accounts and inventories in the west, where St Nicholas, Bristol, is an unusual example of a parish church observing the custom.

12 See Stokes with Alexander, Somerset including Bath, 1.128. See Joan Greatrex, "The Almonry School of Norwich Cathedral Priory in the Thirteenth and Fourteenth Centuries', The Church and Childhood, Diana Wood (ed) (Oxford, 1994), 174-5, 177-8, for a revealing discussion of the term 'clerici sancti Nicholai'. The Norwich Priory records use the term 'clerici' as an alternative to 'pueri' in payments clearly relating to the boy bishop ceremony: 'The terms were presumably interchangeable when applied to boys who were old enough to be clerks in minor orders' (178).

13 For Tavistock, see Orme, Education in the West, 212; accounts do not survive. 14 See Stokes with Alexander, Somerset including Bath, 1.415. 
15 The record, as transcribed by Peter Greenfield, from the Account of Alms, Edward I, reads 'Item clericis ludentibus miracula sancti Nicholai \& eorum Episcopo de elemosina Regis xxvj s viij d'. See Audrey Douglas and Peter Greenfield (eds), Cumberland/Westmorland/Gloucestershire, REED (Toronto, 1986), 290, and Clopper, 'Miracula,' 890, 895. For further details on the school run by the canons of Llanthony, see Orme, Education in the West, 58-65.

16 Orme, Education in the West, 62.

17 The 'Sermon of the Child Bishop, Pronownsyd by John Stubs, querester, on Childermas Day, at Glocester, 1558', now forms part of BL: Cotton Vespasian A.XXV (f $173 \mathrm{ff}$ ), as noted by E.K. Chambers, The Mediaeval Stage, vol 1 (Oxford, 1903), 358, n. 7. It was edited by John Gough Nichols in 'Two Sermons preached by the Boy Bishop at St. Paul's, temp. Henry viII, and at Gloucester, temp. Mary', Camden Miscellany VII, Camden Society, vol 14 (London, 1875).

18 See Mark C. Pilkinton (ed), Bristol, ReEd (Toronto, 1997), 9. See also David Harris Sacks, The Widening Gate: Bristol and the Atlantic Economy, 14501700 (Berkeley, 1991), 180-3, for an analysis of the custom's political significance.

19 Orme, Education in the West, 38.

20 See David Hugh Farmer, The Oxford Dictionary of Christian Saints, 3rd ed (Oxford, 1992), 197, and The Register of Henry Chichele: Archbishop of Canterbury 1414-1443, E.F. Jacob (ed), Canterbury and York Society, vol 46 (Oxford, 1945), vol 3, 8-10.

21 See, for example, Francis Bond, Dedications \& Patron Saints of English Churches: Ecclesiastical Symbolism, Saints and Their Emblems (London, 1914), 17, where St George holds twentieth position in popularity in England, with 126 dedications.

22 See Lawrence M. Clopper (ed), Chester (Toronto, 1979), 261-2.

23 See, for example, Wasson, 'St. George and Robin Hood Plays,' 66, although he points out that information about them is 'quite meagre'. Davidson identifies another problem, relating to the untangling of the St George folk play/ mumming tradition from more devotional saint plays ("Middle English Saint Plays', 60).

24 See Wasson, 'St. George and Robin Hood Plays, 66-7; Davidson, 'The Middle English Saint Play', 65; Ian Lancashire, Dramatic Texts and Records of Britain: A Chronological Topography to 1558 (Toronto, 1984), 228-9 (item 1189). Other records which tempt misinterpretation come from Dartmouth where a St George's gathering is recorded only for 1533-4 (surviving accounts are few). A couple of other payments in 1540-1 and 1541-2 for 'skowryng' 
St George's helmet are likely for an image in the church and unrelated (see Wasson, Devon, 63).

25 See J. Erskine Binney (ed), The Accounts of the Wardens of the Parish of Morebath, Devon, 1520-1573 (Exeter, 1904), 32, and Wasson, Devon, 208-9.

26 See Wasson, Devon, 210, and 'St. George and Robin Hood Plays', 66.

27 On parish guild responsibilities, see Duffy, Stripping of the Altars, 141-54.

28 See Wasson, Devon, 209; see also his 'St. George and Robin Hood Plays', 66, and the $M E D$, 'sete' (variant spelling 'cete').

29 A receipt recorded from 'pe plears at ester here' in 1534 would have occurred around 5 April, a couple of weeks before St George's tide, and may have been payment for use of the church by a visiting troupe (Morebath was not far from a main route from Exeter to the north coast of Devon and Somerset). For the 1534 and 1540 accounts, see Wasson Devon, 209, and also Binney, (ed), Accounts of the Wardens of the Parish of Morebath, $114 \mathrm{ff}$, for more complete context of the 1540 accounts. Boards and trestles, platters, trenchers, and cloths stored in the church house (presumably for the ale and other parish occasions) are also noted in detail in the 1542 accounts. See Binney, Accounts, 124.

30 Duffy, Stripping of the Altars, 497-9.

31 BL: Harley 2125, f 27v (see Clopper, Chester, xxxvii-xxxviii, 8).

32 See Pilkinton, Bristoh 8.

33 See David N. Klausner (ed), Herefordshire/Worcestershire, REED (Toronto, 1990), 114-15.

34 See Clopper, Chester, 258-60, and Stokes with Alexander, Somerset including Bath, 1.372.

35 See Stokes with Alexander, Somerset including Bath, 1.267-8, 334, 340, 352 , 372 , and 377.

36 See extracts from Pro: E 315/122, ff 19v-22, in C.E. McGee and Rosalind Conklin Hays/Sally L. Joyce and Evelyn S. Newlyn (eds), Dorset/Cornwall, REED (Toronto, 1999), 499-500.

37 See Davidson, 'The Middle English Saint Play', 63-5, and David Galloway (ed), Norwich 1540-1642, REED (Toronto, 1984), xxvii-xxviii.

38 See McGee et al, Dorset/Cornwall, 543-4. For details of the life and cult of Meriasek (or Meriadoc, in Breton), see Gilbert H. Doble, The Saints of Cornwall, Part 1: Saints of the Land's End District (Chatham, 1960), 111-45, and for a discussion of the play and its origins, see Brian Murdoch, Cornish Literature (Cambridge, 1993), 99-126.

39 See Eamon Duffy, 'Holy Maydens, Holy Wyfes: The Cult of Women Saints in Fifteenth- and Sixteenth-Century England', in Women in the Church, W.J. Sheils and Diana Wood (eds) (Oxford, 1990), 175-96. 
40 Duffy, 'Holy Maydens, Holy Wyfes', 185. St Katherine is twenty-sixth on Francis Bond's list of saints in order of popularity, with sixty-two dedications (Dedications of Patron Saints, 17).

41 Clopper, 'Communitas', 87-8.

42 The payments are accounted for on 2 June, two days after Corpus Christi by three of Shrewsbury's governing Six Men (J.A.B. Somerset (ed), Shropshire, REED, vol 1 (Toronto, 1994), 183-4).

43 Expenses accounted for (not all of which are itemized) total more than $£ 10$. 44 See Somerset, Shropshire, 2.363, 378, and Bill Champion, Everyday Life in Tudor Shrewsbury (Shrewsbury, 1994), 101.

45 For further description of the quarry, see Somerset, Shropshire, 2.387-8, and for the full context of the play record, 1.171-2. Clopper, 'Communitas', 88, tentatively dismisses this record also as a 'sight' accompanied by musicians (his gloss for 'lusores'). However, there does not seem sufficient reason to doubt this instance as a martyrdom play. 'Lusores' is more usually glossed as 'players' than as 'musicians' and in REED volumes the term seems to refer typically to local players rather than touring professionals, who are more usually designated by terms like 'histriones', 'ministralli', or 'mimi'.

46 See Klausner, Herefordshire/Worcestershire, 11-12, 115-21.

47 See Pilkinton, Bristol, 9, and, for an analysis of its political significance in late medieval Bristol, David Harris Sacks' interesting study, 'The Demise of the Martyrs: The Feasts of St Clement and St Katherine in Bristol, 1400-1600', Social History 11 (1986), 141-69.

48 E. Catherine Dunn, 'The Origin of the Middle English Saints' Plays', The Medieval Drama and Its Claudelian Revival, E. Catherine Dunn, Tatiana Fotitch, and Bernard M. Peebles (eds) (Washington, DC, 1970), 1.

49 There was a rich tradition of saint plays in France, for example. See Lynette Muir, 'The Saint Play in Medieval France', The Saint Play in Medieval Europe, Clifford Davidson (ed), Early Drama, Art, and Music Series 8 (Kalamazoo, MI, 1986), 123-80.

50 Not included are undesignated 'miracula' such as the one at Carlisle (31 July 1345) (Douglas and Greenfield, Cumberland/Westmorland/Gloucestershire, 63-5), routine civic feasts, church ales, or items relating to King Roberr of Sicily at Chester (1529) (Clopper, Chester, 26), and Julian the Apostate at Shrewsbury (1556-7) (Somerset, Shropshire, 1.205), sometimes considered in the same category as saint plays. Clopper speculates about the nature of the Carlisle 'miracula' in Cumberland in 'Miracula', 880-1, 885. 